\title{
Conservative treatment of enamel hypomineralization: microabrasion and bleaching for re-estabilishing esthetics
}

Leonardo Fernandes da Cunha ${ }^{\mathrm{a}}$, Juliana Feltrin de Souza ${ }^{\mathrm{a}}$, Marina Samara Baechtold ${ }^{\mathrm{b}}$, Gisele Maria Correr ${ }^{a}$, Bruna Luiza Nescimento ${ }^{a}$, Carla Castiglia Gonzaga ${ }^{a}$

\begin{abstract}
Objective: Dental hypomineralization such as dental fluorosis has increased in recent times, which leads to unaesthetic appearance of teeth visible at close quarters. There are different treatment possibilities to improve the aesthetic appearance of hypomineralized enamel described in dental literature. The enamel microabrasion has been a feasible alternative, since it is a fast, safe, conservative, and easy to perform, which promotes good esthetic results. Moreover, this technique is a conservative method that improves the appearance of the teeth without causing significant structural loss. The association of different techniques, such as dental bleaching, can provide good esthetic outcomes, but the etiology, intensity and depth of stain should be considered. Thus, the aim of this article is to describe an easy technique for managing mild to moderate dental fluorosis using microabrasion in association with dental bleaching.

Case Report: First, application of the microabrasion material on the enamel surface was performed with $6 \%$ hydrochloric acid and silicon carbide and then with $37 \%$ phosphoric acid and pumice paste. Subsequently, dental bleaching employing 10\% carbamide peroxide gel was indicated.

Conclusion: This conservative approach may be considered an interesting alternative treatment to remove fluorosis staining and to improve aesthetic appearance.
\end{abstract}

Key words: Dental bleaching; Dental enamel hypoplasia; Dental esthetics; Enamel microabrasion

\section{Tratamento conservador de hipoplasia do esmalte: microabrasão e clareamento para o restabelecimento da estética}

\section{RESUMO}

Introdução: Hipomineralização dental como fluorose dentária tem aumentado nos últimos anos, resultando em prejuízo estético dos dentes e sorriso. Existem diferentes possibilidades de tratamento para melhorar a aparência estética do esmalte hypomineralized. A microabrasão do esmalte tem sido uma alternativa viável, uma vez que é um tratamento rápido, seguro, conservador e de fácil realização, que promove bons resultados estéticos. Além disso, esta técnica melhora a aparência dos dentes sem causar a perda de estrutura significativa dos dentes. A associação de diferentes técnicas, tais como o branqueamento dentário podem proporcionar bons resultados estéticos. Assim, o objetivo deste artigo é descrever uma técnica para o tratamento de fluorose leve a moderada usando microabrasão em associação com clareamento dental.

Relato do Caso: Em primeiro lugar, a aplicação do material de microabrasão na superfície do esmalte foi realizada com ácido clorídrico a 6 \% e o carbeto de silício e, em seguida, com ácido fosfórico e pedra pomes. Posteriormente, foi indicado clareamento dental empregando gel de peróxido de carbamida.

Conclusão: Esta abordagem conservadora pode ser considerada um tratamento alternativo interessante para remover manchas de fluorose e para melhorar a aparência estética.

Palavras-chave: Clareamento dental; Hipoplasia do esmalte dentário; Estética dental; Microabrasão a Professor of Graduate Program in Dentistry, Positivo University, Curitiba, Brazil

${ }^{b}$ Student, Graduate Program in Dentistry, Positivo University, Curitiba, Brazil

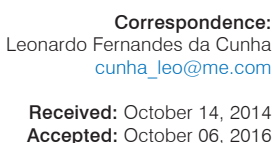

Accepted: October 06, 2016

Conflict of Interests: The authors state that there are no financial and personal conflicts of interest that could have inappropriately influenced their work.

Copyright: (C) 2016 da Cunha et al.; licensee EDIPUCRS.

This work is licensed under a Creative Commons Attribution 4.0 International License. 


\section{INTRODUCTION}

Dental fluorosis is a developmental defect of dental enamel that has increased in recent times. It is caused by excessive exposure to high concentrations of fluoride during tooth development. The severity is affected by the level of fluoride exposition as well as low body weight, skeletal growth rate, and periods of bone remodeling $[1,2]$. Clinically, it is characterized by opacities on the enamel surface, which can vary from distinct white diffuse opacities to brown opacities and enamel depression. This defect in anterior dentition leads to unaesthetic appearance of teeth, causing a negative effect on the smile.

Restorative aesthetic dentistry should be practiced as conservatively as possible. Enamel microabrasion can remove superficial opacities with the association of acid and abrasive material [3]. This procedure provides economy of healthy dental tissues and also supplies aesthetic results [4] Moreover, it is not time-consuming to perform, easy and safe when used appropriately. With the improvement of dental techniques and materials enamel microabrasion can be associated with other therapies.

Every time esthetic procedures are considered, the possibility of conducting dental bleaching should be evaluated. This is as well a conservative procedure that may significantly influence the final result of the smile. Thus, the association of bleaching with other operative procedures is possible and has particular interest in addition to enamel microabrasion [5].

A healthy and harmonious smile has always presented a desire for the patient and a challenge for clinical practice. Gingival health should always be evaluated. This is an aesthetic principle that may significantly influence on the result when a restorative treatment is selected. Additionally, the association of hygiene protocol with other operative procedures is viable and imperative.

As a consequence, this report describes tooth color improvement in patient with dental fluorosis using enamel microabrasion flowed by dental bleaching.

\section{CASE REPORT}

A 15-year-old female was concerned about the discoloration of her maxillary anterior teeth (Figure 1A). Intrinsic white opacities located on the buccal enamel surface of incisors, canines and premolars were verified (Figure 1B). The mothers' patient reported excessive fluoride intake during the critical period of tooth development, including fluoridated drinking water, fluoride toothpaste, dietary fluoride supplements. Thus, dental fluorosis was diagnostic. Various treatment options were discussed and the patient declined any procedure that included preparation of his intact tooth surfaces. It was proposed to use enamel microabrasion to improve the appearance of her teeth.

Initially, dental prophylaxis and periodontal treatment including scaling and root planning was made (Figure 2) and oral hygiene protocol was prescribed. The maxillary teeth
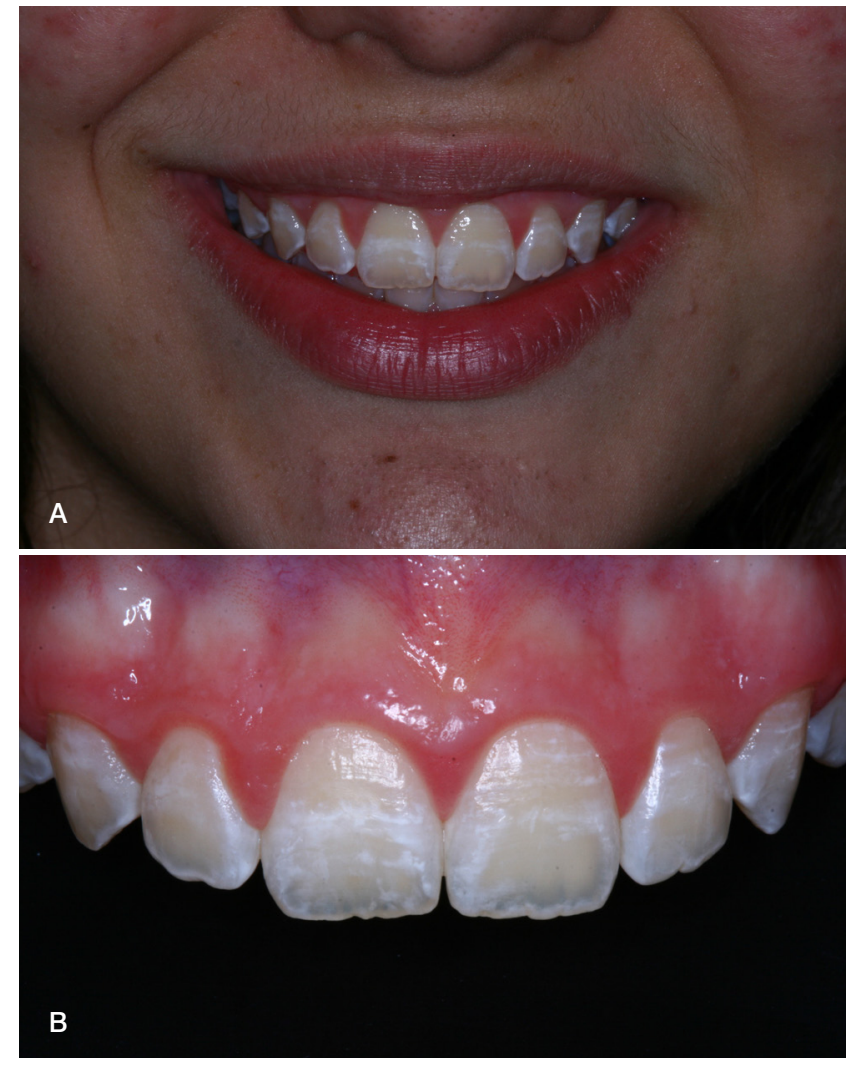

Figure 1. A - Preoperative view of patient's smile. Female with intrinsic stains (dental fluorosis) located on the buccal enamel surface of maxillary teeth. $\mathbf{B}$ - Close-up view of the maxillary anterior teeth. Note the compromised esthetics due to intrinsic white spots and the degree and extent of the marginal inflammation.

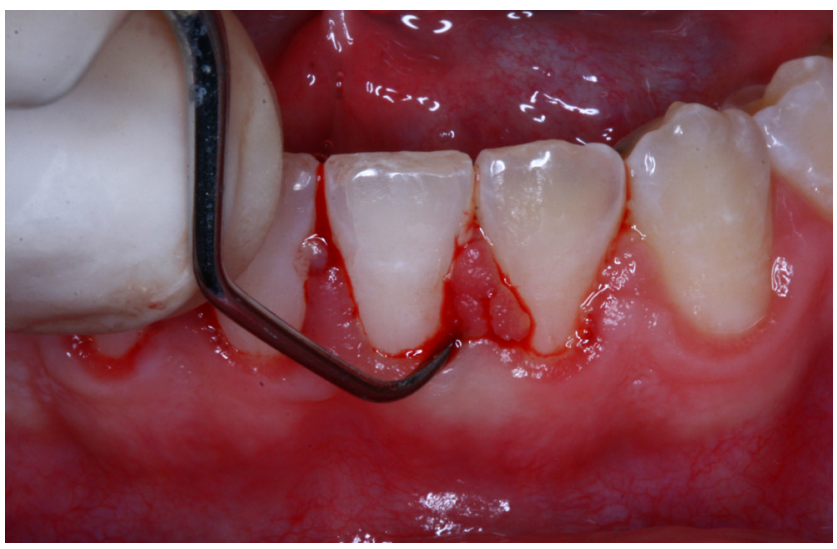

Figure 2. Oral prophylaxis.

to be treated were first cleaned with pumice. The teeth were then isolated with a rubber dam. The patient and operator wore eye protection during the all procedure. A product of $6 \%$ hydrochloric acid and silicon carbide was applied (Whiteness RM - FGM - Joinville, Santa Catarina, Brazil) according the manufactures instructions. A small quantity of the paste was applied on the area corresponding to the opacities for 30 seconds with aid of an instrument provided by the manufacturer (Figure 3). A synthetic rubber tip on a 
gear reduction angle was used to microabrasion the area. After 1 minute of procedure on each tooth, an interval of 1 minute was made and a wash with a water spray between the applications of the compound was done. Then, a second application was done. Thirty-seven percent phosphoric acid gel (3M Scotchbond Etchant; 3M Dental Products, St Paul, Minn) with pumice was used in the last application. Teeth were subsequently washed off, and dried.

Some evidence of a reduction in the intensity of the opacities was evident at that time. The teeth were polished with fine discs (Diamond; FGM - Joinville, Santa Catarina, Brazil). A diamond polishing paste and fluoride were applied to the treated surfaces and the rubber dam was removed. The use this protocol is preferred, because it flows into any roughened enamel surfaces and may also reduce postoperative sensitivity.

The patient was recalled after 2 weeks (Figure 5). Dental bleaching employing $10 \%$ carbamide peroxide gel (Polanight - SDI, Victoria, Australia) was indicated. Impressions were taken and custom trays were made. The patient was instructed to place a tiny drop of the bleaching mixture into each tooth of the tray, from first molar to first

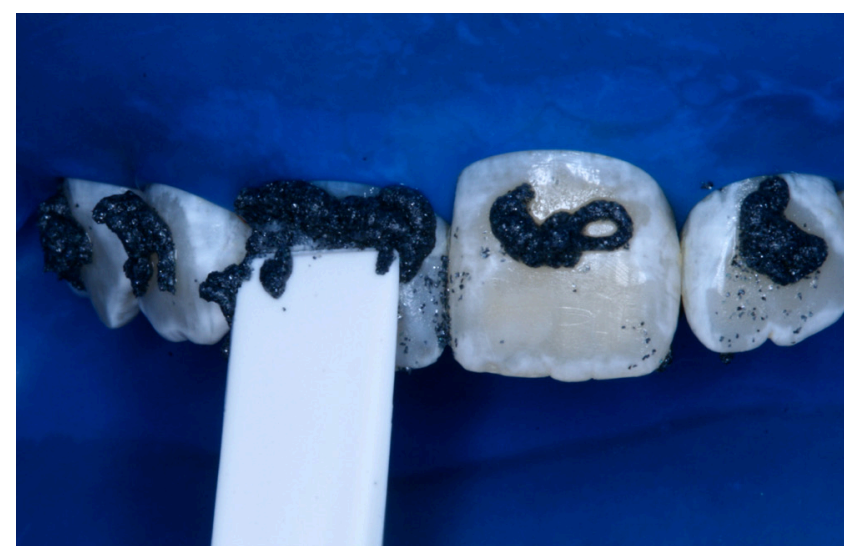

Figure 3. After isolation with a rubber dam, application of the microabrasion material on the enamel surface. The paste was removed with water and air spray and then a new application was performed.

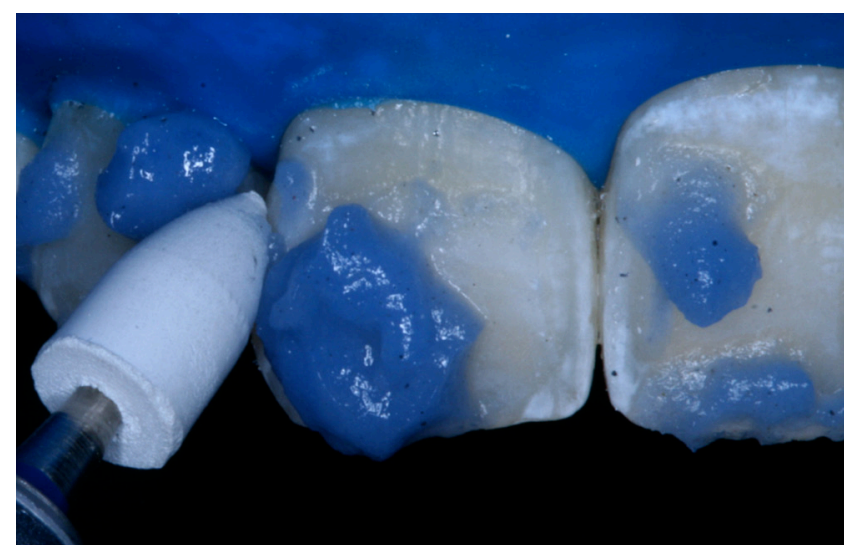

Figure 4. The last application was performed with $37 \%$ phosphoric acid and pumice paste. molar. The trays were inserted and the excess bleaching solution exuding at the margins was wiped away. Bleaching technique was performed 2 hours daily for 3 weeks. After this period, topical application of $2 \%$ neutral- $\mathrm{pH}$ sodium fluoride gel was accomplished. The final result of the smile can be seen in Figure 6.
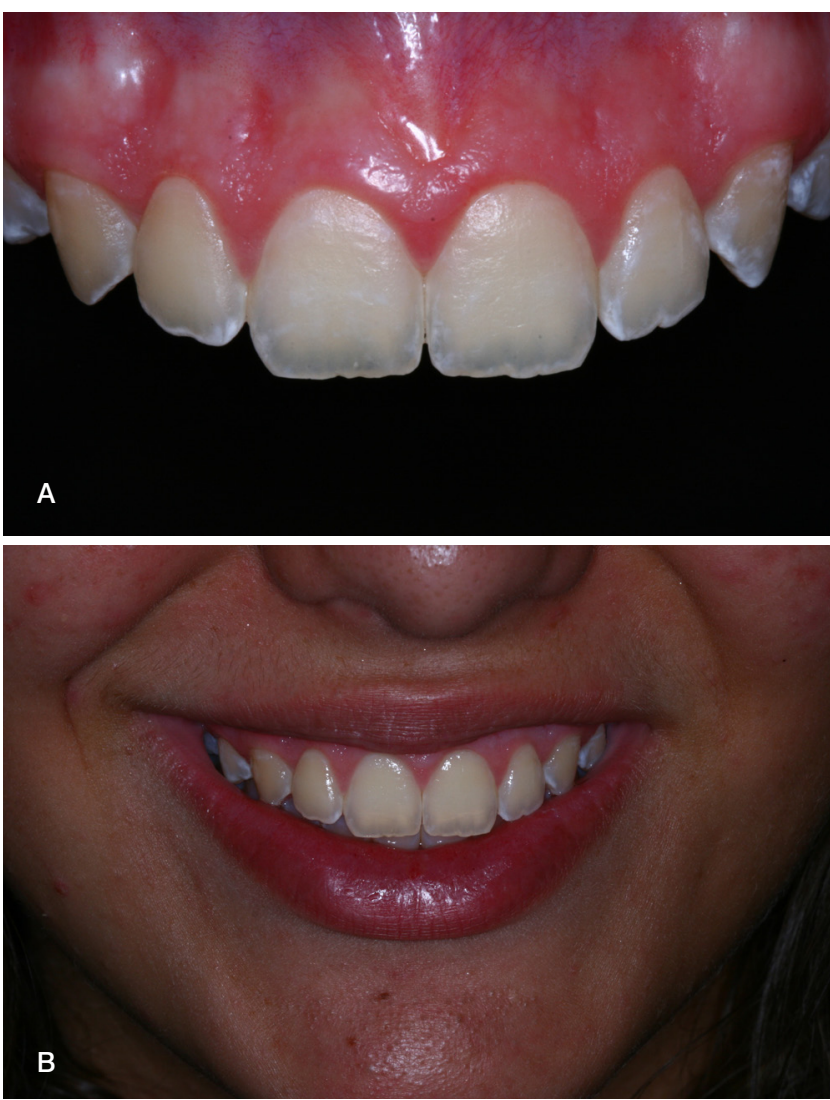

Figure 5. A - Frontal close-up view of the anterior teeth after 1 week. Oral hygiene qualities contributed to improve gingival responses and soft tissue morphology. B - View of the smile after enamel microabrasion

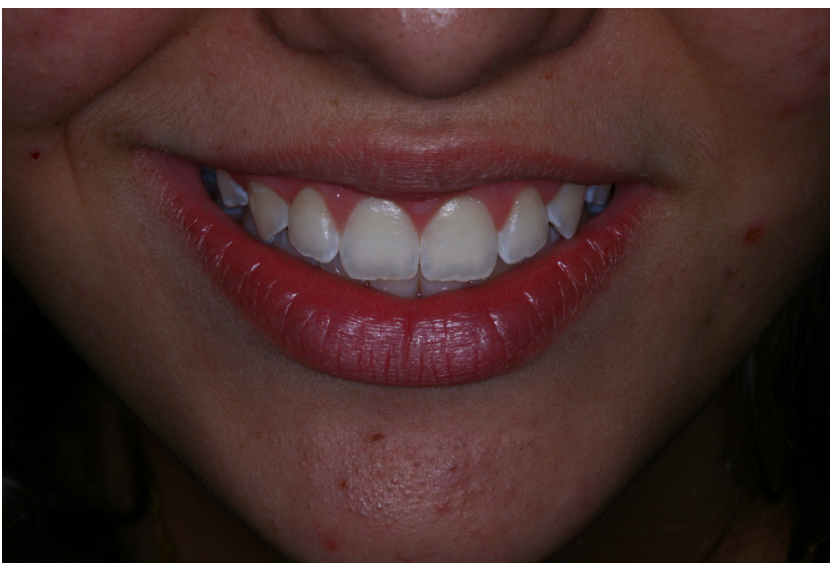

Figure 6. After enamel microabrasion, tooth bleaching was performed with custom-fitted trays containing carbamide peroxide gel. Minimally invasive treatment of the enamel was based on the achievement of healthy, and harmonious smile. 


\section{DISCUSSION}

The enamel formation is genetically controlled, but the environmental, systemic, and mechanical agents can adversely affect the enamel formation during their development. Fluoride have long been recognized for its potential to prevent dental caries, however, the chronic exposure to excessive amounts of fluoride during the amelogenesis can lead to dental fluorosis or mottled enamel. In enamel, fluorosis results in a subsurface hypomineralization [2]. In Brazilian population, the dental fluorosis has been predominantly grades "very mild" and "mild" with no functional impairment [6], nevertheless, an aesthetic problem can be observed. Different treatments can be performed in this situation, such as enamel microabrasion, composite veneers, etc, however, minimum invasive treatment must be preferred.

Enamel hypomineralization can be thoroughly treated by the abrasive action of a microabrasion with pumice and acid solutions as described by Croll e Cavanaugh [7]. Microabrasion can be considered a secure treatment and, furthermore, a conservative alternative [4]. It can be verified in the literature that the enamel loss in teeth after microabrasion ranges from $25 \mu \mathrm{m}$ after each application of the paste $[8,9]$, thus, the dental preparation presented is restricted to the enamel. Hydrochloric acid $(\mathrm{HCl})$ and pumice or $37 \%$ phosphoric acid $\left(\mathrm{H}_{3} \mathrm{PO}_{4}\right)$ and pumice can be used in the technique of enamel microabrasion. Meireles et al. [10] compared the surface roughness and enamel loss produced by these two microabrasion techniques. Under SEM analysis, the authors found that $\mathrm{H}_{3} \mathrm{PO}_{4}$ showed a selective conditioning etching, while $\mathrm{HCl}$ exhibited a nonselective pattern. Microabrasion using $\mathrm{H}_{3} \mathrm{PO}_{4}$ produced greater surface roughness but less demineralization than the microabrasion technique using $\mathrm{HCl}$. Both microabrasion techniques effectively remove the superficial enamel layer. Hydrochloric acid and pumice can be finding in a commercial form, such as the used in the present case. On the other hand, $37 \%$ phosphoric acid $\left(\mathrm{H}_{3} \mathrm{PO}_{4}\right)$ and pumice can be easily produced in the office any time by mixing the phosphoric acid with pumice in 1:1 proportion. The uses of both techniques are possible and well-documented [11], but depends on the professional preference.

It has been verified that teeth submitted to microabrasion acquire a yellowish color because of the thinness of the remaining enamel, revealing the color of dentinal tissue to a greater degree. In these clinical conditions, after enamel microabrasion, home bleaching with hydrogen peroxide can be used, further improving the final result [12] Additionaly, microabrasion make the enamel substrate more susceptible to penetration of peroxide during whitening treatment [13]. Tooth bleaching using peroxide-based materials is an effective procedure in dentistry and many studies provide evidence on the safety of bleaching by dental professionals [14]. As a result, home bleaching was recomended in the present study.

Gingival health should always be evaluated. Good plaque control facilitates the return to health for patients with gingival and periodontal diseases [15]. In the present case, oral instruction and prophylaxis was done before the restorative phase. This sequence will facilitate the restorative procedures and the final esthetic, maintaining lower plaque disease. After enamel microabrasion, a dense, compacted mineral layer remains because of the combined erosive and abrasive action of the compound on enamel surfaces [16]. It has been shown that such surfaces show a higher resistance to demineralization and Streptococcus mutans colonization [17], improving periodontal health in long-term.

The final success of functional or esthetic treatments is only completed when the patient is well-informed and motivated to maintain oral health. The result presented removing the fluorosis stains and bleaching motivated the patient. The patient contribution and periodic control by the dentist is essential to the long-term success of any dental treatment [6].

\section{CONCLUSION}

Enamel microabrasion combined with dental bleaching is a conservative and safe alternative methods to treat enamel opacities from dental flourosis. Therefore, providing satisfactory aesthetic results of patient's smile.

\section{ACKNOWLEDGMENTS}

The authors are also grateful to the manufacturers (FGM and SDI) who donated the products used in this study.

\section{REFERENCES}

1. DenBesten PK. Biological mechanisms of dental fluorosis relevant to the use of fluoride supplements. Community Dent Oral Epidemiol. 1999;27: 41-7. http://dx.doi.org/10.1111/j.1600-0528.1999.tb01990.x

2. Aoba T, Fejerskov O. Dental fluorosis: chemistry and biology. Crit Rev Oral Biol Med. 2002;13:155-70. http://dx.doi.org/10.1177/154411130201300206

3. Sundfeld RH, Croll TP, Briso AL, de Alexandre RS, Sundfeld Neto D. Considerations about enamel microabrasion after 18 years. Am J Dent. 2007;20:67-72.

4. Sundfeld R, Franco L, Goncalves R, de Alexandre R, Machado L, Neto D. Accomplishing Esthetics Using Enamel Microabrasion and Bleaching-A Case Report. Oper Dent. 2013. http://dx.doi.org/10.2341/13-002-S

5. Celik E, Yildiz G, Yazkan B. Comparison of enamel microabrasion with a combined approach to the esthetic management of fluorosed teeth. Oper Dent. 2013;38:134-43. http://dx.doi.org/10.2341/12-317-C

6. da Cunha LF, Tomita NE. Dental fluorosis in Brazil: a systematic review from 1993 to 2004. Cad Saude Publica. 2006;22:1809-16. http://dx. doi. org/10.1590/S0102-311X2006000900011

7. Croll TP, Cavanaugh RR. Enamel color modification by controlled hydrochloric acid-pumice abrasion. I. technique and examples. Quintessence Int. 1986;17:81-7

8. Dalzell DP, Howes RI, Hubler PM. Microabrasion: effect of time, number of applications, and pressure on enamel loss. Pediatr Dent. 1995;17:207-11.

9. Waggoner WF, Johnston WM, Schumann S, Schikowski E. Microabrasion of human enamel in vitro using hydrochloric acid and pumice. Pediatr Dent. 1989;11:319-23.

10. Meireles SS, Andre Dde A, Leida FL, Bocangel JS, Demarco FF. Surface roughness and enamel loss with two microabrasion techniques. J Contemp Dent Pract. 2009;10:58-65.

11. Sinha S, Vorse KK, Noorani H, Kumaraswamy SP, Varma S, Surappaneni H. Microabrasion using $18 \%$ hydrochloric acid and $37 \%$ phosphoric acid in various degrees of fluorosis - an in vivo comparision. Eur J Esthet Dent. 2013;8:454-65.

12. Sundfeld RH, Rahal V, de Alexandre RS, Briso AL, Sundfeld Neto D. Smile restoration through use of enamel microabrasion associated with tooth bleaching. Compend Contin Educ Dent. 2011;32:53-7. 
13. Briso A, Lima A, Goncalves R, Gallinari M, Santos PD. Transenamel and Transdentinal Penetration of Hydrogen Peroxide Applied to Cracked or Microabrasioned Enamel. Oper Dent. 2013. http://dx.doi.org/10.2341/ 13-014-L

14. Ramalho KM, Eduardo Cde P, Rocha RG, Aranha AC. A minimally invasive procedure for esthetic achievement: enamel microabrasion of fluorosis stains. Gen Dent. 2010;58:225-9.

15. Knoernschild KL, Campbell SD. Periodontal tissue responses after insertion of artificial crowns and fixed partial dentures. J Prosthet Dent. 2000;84:492-8. http://dx.doi.org/10.1067/mpr.2000.110262
16. Donly KJ, O'Neill M, Croll TP. Enamel microabrasion: a microscopic evaluation of the "abrosion effect". Quintessence Int. 1992;23:175-9.

17. Segura A, Donly KJ, Wefel JS, Drake D. Effect of enamel microabrasion on bacterial colonization. Am J Dent. 1997;10:272-4 